\title{
TRENDS IN METALLURGICAL SUPPLIERS' SELECTION AND EVALUATION
}

\author{
${ }^{1}$ Radim LENORT, ${ }^{2}$ Eva DONOCIKOVÁ \\ ${ }^{1}$ VSB - Technical University of Ostrava, Faculty of Materials Science and Technology, Ostrava, \\ Czech Republic, EU, radim.lenort@vsb.cz \\ ${ }^{2}$ Bosch Rexroth, spol.s r.o. Brno, Czech Republic, EU, eva.donocikova@boschrexroth.cz
}

https://doi.org/10.37904/metal.2019.977

\begin{abstract}
The aim of the article is to research approaches and trends in the supplier selection and evaluation process in the metallurgical industry with focus on sustainable and resilience assessment. A systematic literature review of scientific articles containing case studies of selection and evaluation of metallurgical suppliers was chosen as a research method. The research has proved that the conventional approach to supplier selection and evaluation is still prevalent in the metallurgical industry. However, the importance of the sustainable and resilient criteria is gradually increasing.
\end{abstract}

Keywords: Metallurgy, supplier selection and evaluation, sustainability, resilience

\section{INTRODUCTION}

Supplier selection and evaluation is one of the important processes of metallurgical supply chain management. It is crucial for a reliable and efficient supply of materials and raw materials. For the selection and evaluation of suppliers are mainly used sets of conventional criteria and their evaluation by means of scoring methods. However, today's turbulent and globalized business environment requires new approaches in supplier relationship management (see e.g. [1-3]). The basic trends in this area include assessing the sustainability and resilience of suppliers. Also, supplier selection and evaluation methods move from simple scoring methods to advanced multi-criteria decision making (MCDM) methods. The aim of the article is to research approaches and trends in the supplier selection and evaluation process in the metallurgical industry. A systematic literature review of scientific articles containing case studies of selection and evaluation of metallurgical suppliers was chosen as a research method.

\section{THEORETICAL BASE AND RESEARCH METHOD}

Nowadays, there are two leading trends in the supply chain management: sustainability and resilience. The following definitions were used in the research work and the article:

- $\quad$ Supply chain sustainability is an ability of the supply chain to balance its economic, environmental and social performance.

- Supply chain resilience is an ability of the supply chain to return to its original state after its serious disruption, i.e. to its original performance.

The systematic literature review was conducted on the basis of the full text scientific articles from the following databases: ProQuest, ScienceDirect, and SpringerLink. We searched for articles that included a real case study focused on the MCDM based selection and evaluation of suppliers from the metallurgical industry. A total of ten articles were identified, but two of them used the same data for the case study (see Table 1). All the case studies were categorized into four groups (see column Approach):

1) Fully conventional (FC) approach - all used selection and evaluation criteria are conventional (e.g. criteria related to quality, price, delivery, technology). 
2) Mostly conventional (MC) approach - most of the criteria are conventional, but there are some criteria related to sustainability and/or resilience. The case studies do not categorize the criteria into conventional, sustainable and/or resilient groups.

3) Conventional-sustainable (CS) approach - the case studies include criteria categorized into two groups: conventional and sustainable.

4) Conventional-sustainable-resilient (CSR) approach - the case studies contain criteria divided into three groups: conventional, sustainable, and resilient.

The metallurgical suppliers can be in two positions (see column Suppliers):

1) Metallurgical producer's supplier - a metallurgical producer selects and evaluates its suppliers (raw materials suppliers).

2) Metallurgical supplier - a customer selects and evaluates its metallurgical suppliers (metallurgical products suppliers).

Table 1 also contains MCDM methodology used, the number of the selection and evaluation criteria used and the number of the selected and evaluated suppliers.

Table 1 Researched case studies and their basic description

\begin{tabular}{|c|c|c|c|c|c|c|}
\hline No. & Approach & $\begin{array}{l}\text { Author(s), year, } \\
\text { source }\end{array}$ & Suppliers & Methodology & $\begin{array}{l}\text { No. of } \\
\text { criteria }\end{array}$ & $\begin{array}{c}\text { No. of } \\
\text { suppliers }\end{array}$ \\
\hline 1 & FC & Kumar et al., 2018 [4] & $\begin{array}{l}\text { Iron and steel } \\
\text { producer's } \\
\text { suppliers (Raw } \\
\text { materials) } \\
\end{array}$ & Fuzzy TOPSIS & 5 & 4 \\
\hline 2 & \multirow{6}{*}{ MC } & Kumar et al., 2019 [5] & $\begin{array}{l}\text { Steel suppliers } \\
\text { (Pipes) }\end{array}$ & $\begin{array}{c}\text { Taguchi loss function, } \\
\text { AHP, TOPSIS }\end{array}$ & 4 & 4 \\
\hline 3 & & Tahiri et al., 2008 [6] & Steel suppliers & AHP & 6 & 4 \\
\hline 4 & & $\begin{array}{l}\text { Punniyamoorthy et } \\
\text { al., } 2011[7]\end{array}$ & $\begin{array}{l}\text { Steel suppliers } \\
\text { (Structural } \\
\text { sections) } \\
\end{array}$ & $\begin{array}{l}\text { Structural equation } \\
\text { modelling, fuzzy AHP }\end{array}$ & 10 & 5 \\
\hline 5 & & $\begin{array}{c}\text { Kumar et al., } 2014 \\
\text { [8]/Jain et al., } 2016 \\
\text { [9] }\end{array}$ & $\begin{array}{l}\text { Steel suppliers } \\
\text { (Tubes) }\end{array}$ & DEA & 9 & 18 \\
\hline 6 & & Kar, 2015 [10] & $\begin{array}{c}\text { Steel producer's } \\
\text { suppliers }\end{array}$ & $\begin{array}{c}\text { Fuzzy AHP, neural } \\
\text { networks }\end{array}$ & 6 & 54 \\
\hline 7 & & Cieśla, 2016 [11] & $\begin{array}{l}\text { Aluminum } \\
\text { suppliers }\end{array}$ & Score weighted method & 7 & 5 \\
\hline 8 & CS & $\begin{array}{l}\text { Mohammed et al., } \\
2019 \text { [12] }\end{array}$ & $\begin{array}{l}\text { Metal producer's } \\
\text { suppliers (Raw } \\
\text { materials) }\end{array}$ & $\begin{array}{l}\text { Fuzzy multi-objective } \\
\text { optimization, fuzzy AHP, } \\
\text { fuzzy TOPSIS, TOPSIS }\end{array}$ & 10 & 3 \\
\hline 9 & CSR & Amindoust, 2018 [13] & $\begin{array}{l}\text { Metal producer's } \\
\text { suppliers }\end{array}$ & Fuzzy set theory, DEA & 12 & 8 \\
\hline
\end{tabular}

The selection and evaluation criteria used in the researched case studies were classified into three groups: conventional, sustainable, and resilient. Global Reporting Initiative (GRI) standards were used to identify sustainable criteria [14]. The standards define sustainability topics for three sustainability dimension: economic, environmental, and social (see Table 2). Criteria identified as sustainable were classified according to the scheme. However, three criteria were so general that they could not be assigned to the sustainability topics and have its original name: environmental competencies, environmental management system, and information disclosure. 
Table 2 GRI sustainability topics [14]

\begin{tabular}{|c|c|}
\hline Economic dimension & Environmental dimension \\
\hline Economic performance & Materials \\
\hline Market presence & Energy \\
\hline Indirect economic impacts & Water \\
\hline Procurement practices & Biodiversity \\
\hline Anti-corruption & Emissions \\
\hline \multirow[t]{3}{*}{ Anti-competitive behavior } & Effluents and waste \\
\hline & Environmental compliance \\
\hline & Supplier environmental assessment \\
\hline \multicolumn{2}{|c|}{ Social dimension } \\
\hline Employment & Rights of indigenous peoples \\
\hline Labor/management relations & Human rights assessment \\
\hline Occupational health and safety & Local communities \\
\hline Training and education & Supplier social assessment \\
\hline Diversity and equal opportunity & Public policy \\
\hline Non-discrimination & Customer health and safety \\
\hline Freedom of association and collective bargaining & Marketing and labelling \\
\hline Child labor & Customer privacy \\
\hline Forced or compulsory labor & Socioeconomic compliance \\
\hline Security practices & \\
\hline
\end{tabular}

The supply chain resilience capabilities defined by Pettit et al. [15] were used to identify and classify resilient criteria:

- $\quad$ Adaptability - ability to modify operations in response to challenges or opportunities.

- $\quad$ Anticipation - ability to discern potential future events or situations.

- $\quad$ Capacity - availability of assets to enable sustained production levels.

- $\quad$ Collaboration - ability to work effectively with other entities for mutual benefit.

- $\quad$ Dispersion - broad distribution or decentralization of assets.

- $\quad$ Efficiency - capability to produce outputs with minimum resource requirements.

- $\quad$ Financial strength - capacity to absorb fluctuations in cash flow.

- $\quad$ Flexibility in order fulfilment - ability to quickly change outputs or the mode of delivering outputs.

- $\quad$ Flexibility in sourcing - ability to quickly change inputs or the mode of receiving inputs.

- $\quad$ Market position - status of a company or its products in specific markets.

- $\quad$ Organization - human resource structures, policies, skills and culture.

- $\quad$ Recovery - ability to return to normal operational state rapidly.

- $\quad$ Security - defense against deliberate intrusion or attack. 
- Visibility - knowledge of the status of operating assets and the environment.

\section{RESULTS AND DISCUSSION}

\subsection{General results}

We can deduce the following research results based on information from Table 1:

- Most of the researched case studies is based on MC approach. There is only one with CS and one with CSR approach, no based on conventional-resilient approach. This shows that the conventional approach to supplier selection and evaluation is still prevalent in the metallurgical industry. On the other hand, selected sustainable and/or resilient criteria are increasingly being introduced into the conventional system.

- From a methodological point of view, the investigated authors offer systems of selection and evaluation of metallurgical suppliers based mainly on the AHP (Analytic Hierarchy Process) and TOPSIS (Technique for Order of Preference by Similarity to Ideal Solution) MCDM method. At the same time, they offer their combination with fuzzy set theory.

- $\quad$ The number of criteria used in the researched case studies varies between 4 and 12 . This shows that it is not appropriate to use too many criteria that reduce the clarity of the supplier selection and evaluation process. On the other hand, using a CSR approach naturally requires a higher number of criteria.

- $\quad$ Although most case studies assessed a relatively small number of suppliers, two of them show that the number of suppliers is not a limiting factor in the application of MCDM methods for the supplier selection and evaluation process.

\subsection{The most important criteria for metallurgical supplier selection and evaluation}

Table 3 summarizes results of the analysis of criteria occurrence and their classification in the researched case studies. Overall, the table shows that conventional criteria are most often used. The most frequent are the following criteria in that group:

- delivery capability,

- quality,

- logistics cost,

- $\quad$ price,

- technological capability,

- location,

- relationship.

In the group of sustainable criteria, the most common are:

- $\quad$ economic performance (economic dimension),

- $\quad$ environmental management system (environmental dimension),

- occupational health and safety (social dimension).

Finally, in the group of resilient criteria:

- financial strength,

- capacity. 
Table 3 Criteria classification and occurrence

\begin{tabular}{|c|c|c|c|c|c|c|c|c|c|c|c|c|}
\hline \multirow{2}{*}{ Group } & \multirow{2}{*}{ Sub-group } & \multirow{2}{*}{ Criterion } & \multicolumn{9}{|c|}{ Case study } & \multirow{2}{*}{ Frequency } \\
\hline & & & 1 & 2 & 3 & 4 & 5 & 6 & 7 & 8 & 9 & \\
\hline \multirow{14}{*}{ Conventional } & & Availability & & & & & & & $\mathrm{x}$ & & & 1 \\
\hline & & Communication system & & & & & $x$ & $x$ & & & & 2 \\
\hline & & Delivery capability & $\mathrm{x}$ & $x$ & $\mathrm{x}$ & $\mathrm{x}$ & $x$ & $x$ & $x$ & $x$ & $x$ & 9 \\
\hline & & Discipline & & & $\mathrm{x}$ & & & & & & & 1 \\
\hline & & Location & & & & $\mathrm{x}$ & $x$ & & $x$ & & & 3 \\
\hline & & Logistics cost & $\mathrm{x}$ & & $\mathrm{x}$ & $\mathrm{x}$ & & & $\mathrm{x}$ & $\mathrm{x}$ & $\mathrm{x}$ & 6 \\
\hline & & Payment terms & & & & $\mathrm{x}$ & & & $x$ & & & 2 \\
\hline & & Price & & $\mathrm{x}$ & $\mathrm{x}$ & $\mathrm{x}$ & $x$ & $x$ & $x$ & & 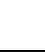 & 6 \\
\hline & & Quality & $\mathrm{x}$ & $\mathrm{x}$ & $\mathrm{x}$ & $\mathrm{x}$ & $\mathrm{x}$ & $\mathrm{x}$ & $\mathrm{x}$ & $\mathrm{x}$ & $\mathrm{x}$ & 9 \\
\hline & & Relationship & . & & $x$ & $\mathrm{x}$ & $x$ & & & & & 3 \\
\hline & & Reputation & $x$ & & & $\mathrm{x}$ & & & ( & & & 2 \\
\hline & & Services & & $\mathrm{x}$ & & $\mathrm{x}$ & & & & & & 2 \\
\hline & & Shelf life & & & & & $x$ & & 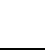 & & 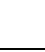 & 1 \\
\hline & & Technological capability & & & $\mathrm{x}$ & $\mathrm{x}$ & & $x$ & & $\mathrm{x}$ & $\mathrm{x}$ & 5 \\
\hline \multirow{9}{*}{ Sustainable } & Economic & Economics performance & $\mathrm{x}$ & & $\mathrm{x}$ & $\mathrm{x}$ & $\mathrm{x}$ & & & & & 4 \\
\hline & \multirow{4}{*}{ Environmental } & Effluents and waste & & & & & & & & $\mathrm{x}$ & & 1 \\
\hline & & Emission & & & ( & & $x$ & & . & $x$ & ( & 2 \\
\hline & & Environmental competencies & & & $\mathrm{x}$ & & & & & & $x$ & 2 \\
\hline & & Environmental management system & & & & $\mathrm{x}$ & & & & $x$ & $x$ & 3 \\
\hline & \multirow{4}{*}{ Social } & Human rights assessment & & & & & & & & & $x$ & 1 \\
\hline & & Information disclosure & & & & & & & & $x$ & & 1 \\
\hline & & Occupational health and safety & & & & $\mathrm{x}$ & & & & $\mathrm{x}$ & $\mathrm{x}$ & 3 \\
\hline & & Training and education & & & & & & & & $x$ & & 1 \\
\hline \multirow{10}{*}{ Resilient } & & Adaptability & & & $\mathrm{x}$ & & & & & & $x$ & 2 \\
\hline & & Capacity & & & $\mathrm{x}$ & $\mathrm{x}$ & & $x$ & & & $x$ & 3 \\
\hline & & Collaboration & & & & & & & & & $\mathrm{x}$ & 1 \\
\hline & & Efficiency & & & & $\mathrm{x}$ & & & & & & 1 \\
\hline & & Financial strength & & & $\mathrm{x}$ & $\mathrm{x}$ & $\mathrm{x}$ & $\mathrm{x}$ & & & & 4 \\
\hline & & Flexibility in order fulfilment & & & & $\mathrm{x}$ & & & & & $\mathrm{x}$ & 2 \\
\hline & & Flexibility in sourcing & & & & & & & & & $x$ & 1 \\
\hline & & Market position & & & & & & & $\mathrm{x}$ & & & 1 \\
\hline & & Organization & & & & $\mathrm{x}$ & & & & & & 1 \\
\hline & & Visibility & & & & $\mathrm{x}$ & & & & & & 1 \\
\hline
\end{tabular}




\section{CONCLUSION}

The research has proved that the conventional approach to supplier selection and evaluation is still prevalent in the metallurgical industry. The most common criteria used are delivery capability, quality, logistics cost, and price. However, the following are criteria from the group of sustainable and resilient criteria: economic performance (sustainable group) and financial strength (resilience group). A surprising finding is that relatively little attention is paid to environmental criteria, although the metallurgical industry is one of the largest polluters.

It is very interesting to compare the results with other industries. While there are a relatively large number of CS or CR based case studies in other sectors (we found ten CS based case studies and three CR base studies from other industries), the study no. 9 is the only one that uses a CSR approach across all sectors. This represents a major research gap in the process of selecting and evaluating industrial suppliers.

The case studies use mainly fuzzy AHP and/or fuzzy TOPSIS methods. However, supplier selection and evaluation criteria are very often interdependent. Thus, future research work should focus rather on ANP (Analytic Network Process) or fuzzy ANP methodologies.

\section{ACKNOWLEDGEMENTS} The work was supported by the specific university research of Ministry of Education, Youth and
Sports of the Czech Republic no. SP 2019/62.

\section{REFERENCES}

[1] RAJNOHA, R., LESNIKOVA, P., KRAJCIK, V. Influence of business performance measurement systems and corporate sustainability concept to overal business performance: "Save the planet and keep your performance". E+M. Ekonomie a Management. 2017. vol. 20, no. 1, pp. 111-128.

[2] STRAKA, M., ROSOVA, A., MALINDZAKOVA, M., KHOURI, S., CULKOVA, K. Evaluating the waste incineration process for sustainable development through modelling, logistics, and simulation. Polish Journal of Environmental Studies. 2018. vol. 27, no. 6, pp. 2739-2748.

[3] BURCHART-KOROL, D. Life cycle assessment of steel production in Poland: A case study. Journal of Cleaner Production. 2013. vol. 54, pp. 235-243.

[4] KUMAR, S., KUMAR, S., BARMAN, A.G. Supplier selection using fuzzy TOPSIS multi criteria model for a small scale steel manufacturing unit. Procedia Computer Science. 2018. vol. 133, pp. 905-912.

[5] KUMAR, R., PADHI, S.S., SARKAR, A. Supplier selection of an Indian heavy locomotive manufacturer: An integrated approach using Taguchi loss function, TOPSIS, and AHP. IIMB Management Review. 2019. vol. 31, pp. 78-90.

[6] TAHRIRI, F., OSMAN, M.R., ALI, A., YUSUFF, R., ESFANDIARY, A. AHP approach for supplier evaluation and selection in a steel manufacturing company. Journal of Industrial Engineering and Management. 2008, vol. 1, no. 2, pp. 54-76.

[7] PUNNIYAMOORTHY, M., MATHIYALAGAN, P., PARTHIBAN, P. A strategic model using structural equation modeling and fuzzy logic in supplier selection. Expert Systems with Applications. 2011. vol. 38, pp. 458-474.

[8] KUMAR, A., JAIN, V., KUMAR, S. A comprehensive environment friendly approach for supplier selection. Omega. 2014. vol. 42, pp. 109-123.

[9] JAIN, V., KUMAR, S., KUMAR, A., CHANDRA, C. An integrated buyer initiated decision-making process for green supplier selection. Journal of Manufacturing Systems. 2016. vol. 41, pp. 256-265.

[10] KAR, A.K. A hybrid group decision support system for supplier selection using analytic hierarchy process, fuzzy set theory and neural network. Journal of Computational Science. 2015. vol. 6, pp. 23-33.

[11] CIESLA, M. Aluminium supplier selection for the automotive parts manufacturer. Metalurgija. 2016. vol. 55, no. 2, pp. 237-240. 
[12] MOHAMMED, A., HARRIS, I., GOVINDAN, K. A hybrid MCDM-FMOO approach for sustainable supplier selection and order allocation. International Journal of Production Economics. Article in press. Available from: https://www.sciencedirect.com/science/article/abs/pii/S0925527319300519.

[13] AMINDOUST, A. A resilient-sustainable based supplier selection model using a hybrid intelligent method. Computers \& Industrial Engineering. 2018. vol. 126, pp. 122-135.

[14] Global Reporting Initiative. GRI Standards. [viewed 2019-02-25]. Available from: https://www.globalreporting.org/standards/.

[15] PETTIT, T.J., FIKSEL, J., CROXTON, K.L. Ensuring supply chain resilience: Development of a conceptual framework. Journal of Business Logistics. 2010. vol. 31, no. 1, pp. 1-22. 